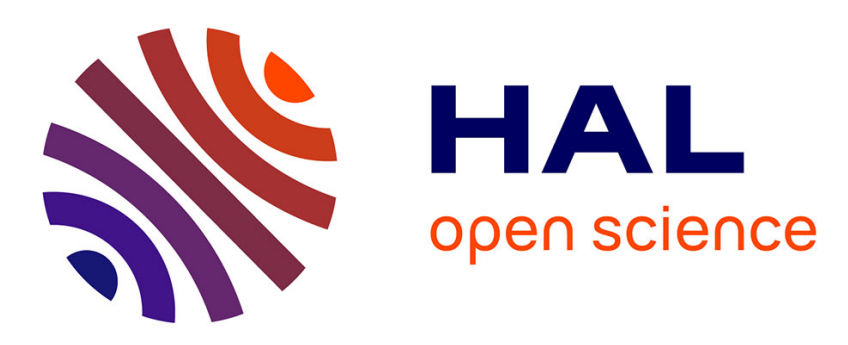

\title{
Effect of phenological stage and proportion of fresh herbagein cow diets on milk fatty acid composition
}

\author{
M. Coppa, Anne Ferlay, G. Borreani, A. Revello-Chion, E. Tabacco, Philippe \\ Pradel, Bruno Martin
}

\section{- To cite this version:}

M. Coppa, Anne Ferlay, G. Borreani, A. Revello-Chion, E. Tabacco, et al.. Effect of phenological stage and proportion of fresh herbagein cow diets on milk fatty acid composition. Animal Feed Science and Technology, 2015, 208, 10.1016/j.anifeedsci.2015.07.006 . hal-01191446

\author{
HAL Id: hal-01191446 \\ https://hal.science/hal-01191446
}

Submitted on 1 Sep 2015

HAL is a multi-disciplinary open access archive for the deposit and dissemination of scientific research documents, whether they are published or not. The documents may come from teaching and research institutions in France or abroad, or from public or private research centers.
L'archive ouverte pluridisciplinaire HAL, est destinée au dépôt et à la diffusion de documents scientifiques de niveau recherche, publiés ou non, émanant des établissements d'enseignement et de recherche français ou étrangers, des laboratoires publics ou privés. 


\title{
Effect of phenological stage and proportion of fresh herbage in cow diets on milk fatty acid composition
}

\author{
M. Coppa ${ }^{\mathrm{a}, *}$, A. Ferlay ${ }^{\mathrm{b}, \mathrm{c}}$, G. Borreani ${ }^{\mathrm{a}}$, A. Revello-Chion $^{\mathrm{d}}$, E. Tabacco $^{\mathrm{a}}$, \\ G. Tornambé ${ }^{\mathrm{b}, \mathrm{c}}$, P. Pradel $^{\mathrm{e}}$, B. Martin ${ }^{\mathrm{b}, \mathrm{c}}$ \\ a University of Turin, Department of Agricultural, Forest and Food Sciences (DISAFA), Largo P. Braccini 2, 10095 Grugliasco (Turin), Italy \\ b INRA, UMR 1213 Herbivores, F-63122 Saint-Genès-Champanelle, France \\ c Clermont Université, VetAgro Sup, UMR Herbivores, BP 10448, F-63000 Clermont-Ferrand, France \\ d Associazione Regionale Allevatori del Piemonte, Via Livorno 60, 10144 Turin, Italy \\ e UE1296 Monts-d'Auvergne, INRA, F-63210 Orcival, France
}

\section{A R T I C L E I N F O}

\section{Article history:}

Received 17 December 2014

Received in revised form 1 July 2015

Accepted 10 July 2015

Available online $\mathrm{xxx}$

\section{Keywords:}

Milk fatty acids

Herbage phenological stage

Fresh herbage proportion

Dairy farming system

\begin{abstract}
A B S T R A C T
The aim of this work was to test the effect of herbage phenology on the fatty acid (FA) composition of milk and its interaction with fresh herbage proportion in cow diets in controlled conditions, as well as to validate the results in on-farm conditions. Three experiments were conducted in controlled conditions, and were designed to be representative of dairy systems with increasing fresh herbage proportions in cow diets: low (25\% of diet dry matter (DM)); high (75\% of diet DM), and full grazing (100\% of diet DM). The fourth experiment was a survey conducted in commercial farms that adopt feeding systems similar to those of controlled conditions. An overall effect of herbage phenology on milk FA composition was observed. The number of FA that were affected by herbage phenology was higher as the proportion of fresh herbage in the cow diets increased. The C16:0, total even chain saturated FA, odd chain FA, branched-chain FA, C18:1c9, and monounsaturated FA concentrations in milk increased with increasing herbage phenology, whereas the de novo synthesized FA, C18:1t11, CLAc9t11, C18:3n-3 and total polyunsaturated FA concentrations decreased. When low proportions of fresh mature herbage was fed to cows, the FA profile of the derived milk differed from the control diet (without fresh herbage) only for the higher concentrations of $\mathrm{C} 18: 1 \mathrm{t} 11$, CLAc9t11, and $\mathrm{C} 18: 3 n-3$, whereas the differences were greater and significant for several FA for similar proportions of fresh herbage at an early phenological stage. The results obtained in controlled conditions were confirmed onfarm: the C18:1t11 and CLAc9t11 were the most sensitive FA to the effect of fresh herbage phenology. However, when low fresh herbage proportion were used in cow diets, the effect of herbage phenology on milk FA concentration was negligible.
\end{abstract}

(c) 2015 Elsevier B.V. All rights reserved.

Abbreviations: ADF, acid detergent fiber; aNDF, neutral detergent fiber; BCFA, sum of branched-chain FA; CLA, conjugate linoleic acid; CP, crude protein; de novo FA, sum of de novo synthetized FA; ECSFA, sum of even-chain saturated FA; FA, fatty acid; DM, dry matter; MUFA, sum of monounsaturated FA; OCFA, sum of odd-chain FA; OMD, organic matter digestibility; PUFA, sum of polyunsaturated FA; SFA, saturated FA; TMR, total mixed ration.

* Corresponding author.

E-mail address: mauro.coppa@unito.it (M. Coppa). 


\section{Introduction}

In Europe, grasslands occupy about 39\% of the utilized agricultural area, and grazing dairy cows account for about 24 million grazing livestock units (Peeters, 2012). Thus, pasture-based dairy farming systems play a key role in European milk production. These systems are also interesting because of the high nutritional value of the produced milk, in particular referring to the fatty acid (FA) composition. Feeding cows with fresh herbage increases milk polyunsaturated FA (PUFA), conjugated linoleic acids (CLA) and $n-3$ FA and decreases saturated FA (SFA) and $n-6$ FA concentrations in milk (Shingfield et al., 2013; Chilliard et al., 2007; Dewhurst et al., 2006), and thus a more favorable FA profile is reached for human health (Kratz et al., 2013; Givens, 2010). Recently, some dairy companies, in various EU countries (i.e. France, Belgium, The Netherlands), have applied a price premium for cow milk rich in FA with a putative positive effect on health (i.e. high concentrations of $n-3$ and PUFA, and low concentrations of SFA) (Borreani et al., 2013). However, the FA composition of pasture-derived milk and dairy products varies to a great extent according to herbage characteristics and diet formulation (i.e. forage-to-concentrate ratio) (Chilliard et al., 2007; Dewhurst et al., 2006), whereas animal related factors (i.e. breed and lactation stage) have been shown to have negligible effects (Coppa et al., 2013; Ferlay et al., 2006). The relationships between the botanical composition of a pasture and FA concentrations of milk have been studied in depth, both in controlled conditions (Coppa et al., 2011; Ferlay et al., 2006) and in on-farm conditions (Revello-Chion et al., 2010; Bugaud et al., 2002; Collomb et al., 2002). However, some factors other than botanical composition, such as grazing management, and animal characteristics may affect milk FA profile (Coppa et al., 2015; Couvreur et al., 2006). Herbage phenological stage can also play an important role, as variations in the FA concentration of herbage have been reported to vary accordingly by several authors (Glasser et al., 2013; Buccioni et al., 2012; Khan et al., 2012). The effects of herbage phenology on milk yield and FA composition have been studied in sheep grazing on different Mediterranean species of forages or their mixtures (reviewed by Cabiddu et al., 2005). These authors have shown an increasing trend of C18:3n- 3 and rumenic acid (CLAc9t11) with herbage maturity. On the contrary, Vanhatalo et al. (2007) have shown a progressive decrease in both these FA and PUFA concentration in milk with increasing herbage maturity, when cows were fed ensiled temporary grasslands at different phenological stages. Similar results have recently been found by Kälber et al. (2014) for C18:3n - 3, but not for CLAc9t11, when cows were fed indoors with fresh herbage at vegetative and reproductive stages. However, little is known about how fresh herbage phenology interacts with various proportions of fresh herbage in cow diets on milk FA concentrations.

The work was aimed at evaluating the effect of herbage phenological stage, and its interaction with different fresh herbage proportion in cow diet (corresponding to increasing intensification of production conditions), on FA composition of milk in controlled conditions, and at verifying the results on-farm.

\section{Materials and methods}

\subsection{Animals and feeding treatments}

Three experiment with increasing proportion of fresh herbage in cow diet have been conducted in controlled conditions (Experiments 1,2 and 3) and a farm survey has been carried out on commercial dairy farms with feeding systems similar to those studied in the controlled conditions (Experiment 4). Experiments 1 and 2 were carried out at the INRA experimental farm of Marcenat in an upland area in central France $\left(45^{\circ} 15^{\prime} \mathrm{N}, 2^{\circ} 55^{\prime} \mathrm{E}\right.$; altitude $1135-1215 \mathrm{~m}$; annual rainfall $\left.1100 \mathrm{~mm}\right)$, while Experiment 3 was conducted on a commercial farm located in Scarnafigi (CN), in the Piedmont lowlands, in NorthWest Italy ( $44^{\circ} 41^{\prime} \mathrm{N}, 7^{\circ} 34^{\prime} \mathrm{E}$, altitude $295 \mathrm{~m}$; annual rainfall $730 \mathrm{~mm}$ ). The farms involved in Experiment 4 were distributed throughout the Torino and Cuneo Provinces in Piedmont, in North-West Italy, as described hereafter.

\subsubsection{Experiment 1: Full grazing}

After a two-week pre-experimental period, during which 18 winter-calving Montbéliarde cows grazed on the same pasture, cows were divided into three equivalent groups of six, considering body weight $(612 \pm 9.1 \mathrm{~kg})$, milk yield $(18.0 \pm 0.4 \mathrm{~kg} / \mathrm{cow} \times$ day $)$, milk fat and protein contents $(37.5 \pm 0.43$, and $31.9 \pm 0.22 \mathrm{~g} / \mathrm{kg}$ of milk, respectively), days in milk $(177 \pm 7.0)$, and parity. The three groups were assigned to three pasture plots, differing for floristic diversity, in order to understand the effect of the evolution of herbage phenology on different pasture types: a temporary grassland; a moderately biodiversified permanent grassland; and a highly biodiversified permanent pasture. Cows did not receive any concentrate supplementation. During the 3-week experiment on the first growth cycle, cows grazed during day and night by strip grazing (electric fences were moved forward every two days). Individual milk samples were collected once a week at weeks 1 and 3 , which corresponded to the early (stem elongation) and late (late flowering) herbage phenological stages.

\subsubsection{Experiment 2: Intermediate fresh herbage proportion}

A group of 5 Montbéliarde winter-calving dairy cows ( $594 \pm 14.1 \mathrm{~kg}$ of body weight; $15.1 \pm 1.5 \mathrm{~kg} / \mathrm{cow} \times$ day of milk yield; $109 \pm 11.9$ days in milk) strip-grazed a botanically diversified pasture, for four consecutive weeks in the first growth cycle. Cows were supplemented with $3.8 \mathrm{~kg} / \mathrm{cow} \times$ day of a commercial concentrate (on a dry matter (DM) basis, wheat, $37.3 \%$, bran, $22.6 \%$, wheat gluten, $14.4 \%$, sunflower cake, $5.4 \%$, rapeseed cake, $4.6 \%$, cereal by-products, $10.0 \%$, molasses, $2.5 \%$, and carbonate, minerals and vitamins, $3.2 \%$ ), and fresh herbage represented about $75 \%$ of the dietary DM. Individual milk samples 
were collected once a week at weeks 1 and 4, which corresponded to the early (stem elongation) and late (late flowering) herbage phenological stages.

\subsubsection{Experiment 3: Low fresh herbage proportion}

Twelve high-yielding Holstein dairy cows were divided into three homogeneous groups considering milk yield $(31 \pm 0.83 \mathrm{~kg} / \mathrm{cow} \times$ day), days in milk $(176 \pm 7.8)$, and body weight $(721 \pm 12.4 \mathrm{~kg})$. The first two groups received a total mixed ration (TMR) supplemented with fresh harvested herbage (mainly Lolium multiflorum), which represented about 25\% of the diet DM, distributed over early (steam elongation) or late (late flowering) phenological stages, respectively. The third group (used as a control) received the same TMR, without fresh herbage supplementation. All the groups received more than $10 \mathrm{~kg} / \mathrm{cow} \times$ day of concentrate. After a two-week period of adaptation to the diets, the milk was sampled for three consecutive days at each milking.

\subsubsection{Experiment 4: On-farm survey}

Sixty bulk milk samples from grazing herds on commercial farms were collected over a whole grazing season. The farms were selected to be representative of the three production systems considered in the previously mentioned controlled experiments. During each milk sampling, the production conditions and herbage phenological stages were recorded thought on-farm surveys, as described by Borreani et al. (2013). Milk samples were grouped into three groups according to the fresh herbage proportion in cow diet: Low, Intermediate and Full grazing, with fresh herbage proportions in the cow diets of about 20,75 and $100 \%$, respectively. Milk samples in each group were classified according to the herbage phenological stages: early phenological stage (Early), from vegetative stage to grass stem elongation; and late phenological stage (Late), from flowering to grass grain maturity.

\subsection{Vegetation surveys, sampling and chemical analysis}

The herbage botanical composition was determined through botanical surveys (Braun-Blanquet, 1932). A representative herbage subsample (as well as a sample of the TMR from Experiment 3) was analyzed for the DM content by oven drying at $80^{\circ} \mathrm{C}$ for $48 \mathrm{~h}$ (Dulphy et al., 1999) and another subsample was dried for qualitative analyses in a forced-draft oven to a constant weight at $65^{\circ} \mathrm{C}$, air equilibrated, weighed and ground in a Cyclotec mill (Tecator, Herndon, VA, USA) to pass a $1 \mathrm{~mm}$ screen. The ground samples were analyzed for crude protein (CP) (total $N \times 6.25$ ), according to the Dumas method ( $m e t h o d$ number 992.23, AOAC, 2005), using a Nitrogen analyser (Primacs SN, Skalar, Breda, The Netherlands), and for pepsin-cellulase solubility (Aufrère and Michalet-Doreau, 1983) as a measure of the organic matter digestibility (OMD). Neutral detergent fiber (aNDF) was analyzed using a Raw Fiber Extractor (FIWE, VELP Scientifica, Usmate Velate, Italy) with the addition of heat-stable amylase (A3306, Sigma Chemical Co., St. Louis, MO) and expressed on a DM basis including residual ash, as described by Van Soest et al. (1991). Acid detergent fiber (ADF) and acid detergent lignin were analyzed (Robertson and Van Soest, 1981) and expressed on a DM basis including residual ash. The starch concentration was determined according to the AOAC method (method number 996.11; AOAC, 2005), using a K-TSTA assay kit (Megazyme International, Bray, Ireland).

\subsection{Milk sampling and analyses}

Individual milk samples in Experiments 1, 2 and 3 were pooled in 60:40 ratio for morning and evening milkings of the sampling day, respectively, while the bulk milk was collected directly from the farm tank in Experiment 4 . Milk fat and protein contents were measured on a subsample by Fourier transform infrared spectroscopy (MilkoScan FT6000, Foss System, Hillerød, Denmark). After having lyophilized (Thermovac TM-20; Froilabo S.A., France) other milk subsamples for FA analysis, they were methylated and analyzed according to Coppa et al. (2015). The FA methyl esters were injected $(0.6 \mu \mathrm{L})$, by mean of an auto-sampler, into a gas chromatograph equipped with a flame ionization detector (Agilent Technologies 7890A, Wilmington, USA). The FA methyl esters from all the samples were separated on a $100 \mathrm{~m} \times 0.25 \mathrm{~mm}$ i.d. fused-silica capillary column (CP-Sil 88, Chrompack, Middelburg, The Netherlands). The injector temperature was maintained at $255^{\circ} \mathrm{C}$ and the detector temperature at $260^{\circ} \mathrm{C}$. The initial oven temperature was held at $70^{\circ} \mathrm{C}$ for $1 \mathrm{~min}$, increased to $100^{\circ} \mathrm{C}$ at a rate of $5^{\circ} \mathrm{C} / \mathrm{min}$ (held for $2 \mathrm{~min}$ ), and then increased by $10^{\circ} \mathrm{C} / \mathrm{min}$ to $175^{\circ} \mathrm{C}$ (held for $42 \mathrm{~min}$ ), and $5^{\circ} \mathrm{C} / \mathrm{min}$ to a final temperature of $225^{\circ} \mathrm{C}$ (held for $15 \mathrm{~min}$ ). The carrier gas was hydrogen and pressure was maintained constant (158.6 kPa) during analysis. Peaks were routinely identified by comparing retention times against commercial authentic standards. The FA methyl esters proportions were corrected to the FA proportions, according to their respective molecular weight.

\subsection{Statistical analyses}

Statistical analyses were performed using the SPSS for Windows software package (version 17.0; SPSS Inc., Chicago, IL). In the controlled experiments, data were processed using the repeated measure model of analysis of variance. In Experiment 1 , the sampling period was the repeated factor, whereas the fixed factors were pasture type, and pasture type $\times$ period interaction. In Experiment 2, the herbage phenological stage was tested as a repeated factor. In Experiment 3, the sampling day was the repeated factor, whereas the dietary treatment, and dietary treatment $\times$ period interaction were the fixed factors. As neither the day of sampling nor the interaction were found to be significant, only the data about the significance of the 
Table 1

Botanical composition of the plots used for the three controlled experiments.

\begin{tabular}{|c|c|c|c|c|}
\hline \multirow[t]{2}{*}{ Item } & \multirow[t]{2}{*}{ No. of species } & \multicolumn{3}{|c|}{ Proportion of ground cover (\%) } \\
\hline & & Total & Species $>10$ & Species $1-10$ \\
\hline Experiment 1: temporary grassland & 17 & & & \\
\hline Grasses & 5 & 76.2 & $\begin{array}{l}\text { Dactylis glomerata, } \\
\text { Lolium perenne }\end{array}$ & Elymus repens, Poa annua \\
\hline Legumes & 1 & 7.1 & & Trifolium repens \\
\hline Other species & 11 & 16.7 & & $\begin{array}{l}\text { Taraxacum officinale, Capsella bursa-pastoris, } \\
\text { Plantago major }\end{array}$ \\
\hline $\begin{array}{l}\text { Experiment } 1 \text { moderately } \\
\text { biodiversified pasture }\end{array}$ & 31 & & & \\
\hline Grasses & 13 & 73.6 & $\begin{array}{l}\text { Dactylis glomerata, } \\
\text { Alopecurus pratensis }\end{array}$ & $\begin{array}{l}\text { Poa pratensis, Festuca rubra, Phleum pratense, } \\
\text { Bromus mollis, Agrostis tenuis, Arrhenaterum } \\
\text { elatius, Trisetum flavescens }\end{array}$ \\
\hline Legumes & 3 & 7.1 & & Trifolium repens, Lathyrus pratensis \\
\hline Other species & 15 & 19.3 & & $\begin{array}{l}\text { Stellaria graminea, Achillea millefolium, } \\
\text { Cerastium glomeratum, Stellaria media, Veronica } \\
\text { chamaedrys, Cerastium funtanum, Alchemilla } \\
\text { vulgaris }\end{array}$ \\
\hline $\begin{array}{l}\text { Experiment } 1 \text { highly biodiversified } \\
\text { pasture }\end{array}$ & 50 & & & \\
\hline Grasses & 14 & 52.3 & $\begin{array}{l}\text { Festuca rubra, Agrostis } \\
\text { capillaris }\end{array}$ & $\begin{array}{l}\text { Festuca ovina, Briza media, Phleum phleoides, } \\
\text { Trisetum flavescens, Poa pratense, Avenula } \\
\text { pubescens }\end{array}$ \\
\hline Legumes & 5 & 1.5 & & Trifolium repens \\
\hline Other species & 31 & 46.2 & & $\begin{array}{l}\text { Thymus pulegioides, Plantago lanceolata, } \\
\text { Achillea millefolium, Veronica chamaedrys, } \\
\text { Galium verum, Gentiana lutea, Rumex acetosella, } \\
\text { Cerastium fontanum, Stellaria graminea, Viola } \\
\text { lutea, Luzula campestris, Cerastium tomentosum, } \\
\text { Conopodium majus }\end{array}$ \\
\hline Experiment 2 & 46 & & & \\
\hline Grasses & 12 & 56.3 & $\begin{array}{l}\text { Festuca rubra, Agrostis } \\
\text { capillaris }\end{array}$ & $\begin{array}{l}\text { Anthoxanthum odoratum, Deshampsia flexuosa, } \\
\text { Briza media, Cynosurus crystatus, Avenula } \\
\text { pubescens }\end{array}$ \\
\hline Legumes & 9 & 5.7 & & $\begin{array}{l}\text { Trifolium repens, Chamaespartium sagittale, } \\
\text { Lotus corniculatus }\end{array}$ \\
\hline Other species & 25 & 38 & & $\begin{array}{l}\text { Hieracium pilosella, Thymus pulegioides, } \\
\text { Genziana lutea, Stachys officinalis, Achillea } \\
\text { millefolium, Galium verum, Helianthemum } \\
\text { nummularium, Meum athamanticum, Potentilla } \\
\text { tebernaemontani, Scabiosa columbaria, Plantago } \\
\text { lanceolata }\end{array}$ \\
\hline Experiment 3 & 14 & & & \\
\hline Grasses & 5 & 86 & Lolium multiflorum & \\
\hline Legumes & 2 & 8 & & Trifolium repens, Trifolium pratense \\
\hline Other species & 7 & 6 & & \\
\hline
\end{tabular}

dietary treatment are reported. In Experiment 4, general linear model of analysis of variance was used, in which the fresh herbage proportion in cow diet, the herbage phenological stage and their interaction were used as fixed factors.

\section{Results}

\subsection{Herbage and feedings composition}

The vegetation of the plots used in the controlled experiments was dominated by grasses (Table 1), with a ground cover that exceeded 70\%, except for the highly biodiversified pastures in Experiment 1 and Experiment 2, in which it was around $50 \%$. The legume contribution to the ground cover was low for all the experimental plots, whereas the contribution of the other families was high, especially for the highly biodiversified pasture (in Experiment 1) and in Experiment 2 ( $>40 \%$ ). The botanical composition of the pastures grazed in the farms involved in the survey showed a numerically lower contribution of grasses to the herbage ground cover than the experimental plots, and a higher contribution of legumes. The legume contribution to ground cover on average was higher than $40 \%$ for the low fresh herbage groups and the late group, in the farms with an intermediate herbage proportion in the cow diet (Fig. 1). The contribution of the other species to the ground cover was over $40 \%$ in both Early and Late groups of the Full grazing farms and in the early group of the farm giving an intermediate fresh herbage proportion in cow diet (Fig. 1). The majority of the farms of Full grazing group grazed during summer on upland pasture (in average about $1800 \mathrm{~m}$ a.s.l.; Table 3), whereas the availability of upland pastures during 


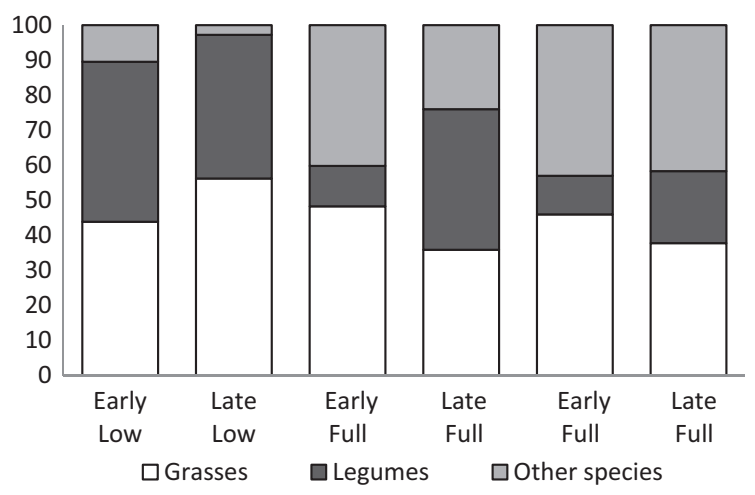

Fig. 1. Proportions of grasses, legumes and other species on total ground cover in the vegetation of the plots grazed by the herd of the commercial farm during the survey. Note: Low, low fresh herbage proportions in cow diet; Int., intermediate fresh herbage proportions in cow diet; Full, full grazing; Early, from grasses steam elongation to booting; Late, from grasses heading to flowering.

summer was less frequent among the farms of the Intermediate group, mainly grazing mountain pasture at an intermediate altitude (on average about $700 \mathrm{~m}$ a.s.l.; Table 3). The Low groups grazed only lowland pastures (Table 3 ).

The DM, aNDF, and ADF contents of the herbage increased numerically, while the CP content and OMD decreased with herbage maturity in Experiments 1 (for all the pasture types), 2 and 3 (Table 2). In Experiment 1, the decrease in CP and OMD was numerically higher for the temporary grassland. The Late fresh herbage had higher DM, aNDF, and ADF contents, and a lower CP content and OMD value than the Early one (Table 2). The TMR starch content was $28.3 \mathrm{~g} / \mathrm{kg}$ DM. The Experiment 3 forage-to-concentrate ratio $(\mathrm{F} / \mathrm{C}$ ) was $65 / 35$ for both the Early and Late groups, and 55/45 for the TMR control group (Table 2).

In Experiment 4, the fresh herbage proportions in cow diet in the Low, Intermediate and Full grazing groups were similar to those applied in the three controlled experiments (Table 3). In the Intermediate group, fresh herbage was supplemented with small amounts of hay (about 16\% of diet DM) and concentrates (about 10\% of diet DM), whereas in the Low group, fresh herbage was supplemented with higher amounts of hay and concentrate (about 25 and 36\% of diet DM, respectively) and with corn silage (about $20 \%$ of diet DM). The herd characteristics and cow diet compositions were similar for the Early and Late sub-groups in the Low, Intermediate and Full grazing groups. Slightly higher values of DM, aNDF, and ADF contents and a lower CP content and OMD value were observed for the fresh herbage in all the Late groups, compared to the Early groups. The chemical composition of the herbage in Experiment 4 was within the range of values of the herbage from the

Table 2

Cow diet composition and nutritive value of herbage (and total mixed ration in Experiment 3) according to herbage phenological stage in the experiments conducted in controlled conditions.

\begin{tabular}{|c|c|c|c|c|c|c|c|c|c|c|c|}
\hline \multirow[t]{3}{*}{ Item $^{\mathrm{a}}$} & \multicolumn{6}{|c|}{ Experiment 1} & \multicolumn{2}{|c|}{ Experiment 2} & \multicolumn{3}{|c|}{ Experiment 3} \\
\hline & \multicolumn{2}{|c|}{$\begin{array}{l}\text { Temporary } \\
\text { grassland }\end{array}$} & \multicolumn{2}{|c|}{$\begin{array}{l}\text { Moderately } \\
\text { biodiversified } \\
\text { pasture }\end{array}$} & \multicolumn{2}{|c|}{$\begin{array}{l}\text { Highly } \\
\text { biodiversified } \\
\text { pasture }\end{array}$} & \multirow[b]{2}{*}{ Early } & \multirow[b]{2}{*}{ Late } & \multirow[b]{2}{*}{ Early } & \multirow[b]{2}{*}{ Late } & \multirow[b]{2}{*}{$\mathrm{TMR}^{\mathrm{e}}$} \\
\hline & Early & Late & Early & Late & Early & Late & & & & & \\
\hline Cow breed & & & & & & & \multicolumn{2}{|c|}{ Montbéliarde } & & \multicolumn{2}{|c|}{ Holstein } \\
\hline Live weight & 614 & 603 & 618 & 603 & 604 & 600 & 594 & 571 & 720 & 718 & 724 \\
\hline Days in milk & 152 & 173 & 150 & 171 & 153 & 174 & 109 & 138 & 169 & 182 & 176 \\
\hline \multicolumn{12}{|l|}{ Diet composition (\% on DM $)^{\mathrm{b}}$} \\
\hline Fresh herbage & 100 & 100 & 100 & 100 & 100 & 100 & 75 & 75 & 25 & 25 & - \\
\hline Conserved forages ${ }^{c}$ & - & - & - & - & - & - & - & - & 40 & 40 & 55 \\
\hline Concentrate - raw materials ${ }^{\mathrm{d}}$ & - & - & - & - & - & - & - & - & 22 & 22 & 28 \\
\hline Commercial concentrate mix & - & - & - & - & - & - & 25 & 25 & 12 & 12 & 16 \\
\hline Forage to concentrate ratio & $100-0$ & $100-0$ & $100-0$ & $100-0$ & $100-0$ & $100-0$ & $75-25$ & $75-25$ & $65-35$ & $65-35$ & $55-45$ \\
\hline $\mathrm{DM}(\%)$ & 16.8 & 20.8 & 21.3 & 27.4 & 27.3 & 33.7 & 20.7 & 40.7 & 19.3 & 24.8 & 55.8 \\
\hline $\operatorname{NDF}(g / 100 g$ DM $)$ & 45.1 & 50.4 & 43.3 & 49.1 & 45.0 & 50.4 & 55.9 & 58.4 & 53.2 & 55.5 & 38.5 \\
\hline $\mathrm{ADF}(\mathrm{g} / 100 \mathrm{~g} \mathrm{DM})$ & 28.4 & 34.4 & 27.0 & 33.3 & 29.0 & 33.3 & 31.0 & 33.2 & 31.0 & 31.5 & 20.4 \\
\hline $\mathrm{CP}(\mathrm{g} / 100 \mathrm{~g} \mathrm{DM})$ & 17.8 & 12.4 & 15.2 & 13.1 & 13.8 & 13.2 & 13.3 & 11.2 & 15.3 & 13.0 & 17.2 \\
\hline OMD (\%) & 77.7 & 71.8 & 74.0 & 69.6 & 74.0 & 71.9 & 69.0 & 64.5 & 69.9 & 68.3 & 82.9 \\
\hline
\end{tabular}

a Early, grasses between stem elongation and booting; Late, grasses between heading and flowering; DM, dry matter; NDF, neutral detergent fiber; ADF, acid detergent fiber; $\mathrm{CP}$, crude protein; OMD, organic matter digestibility; TMR, total mixed ration.

b All the diets were balanced to satisfy animal mineral requirements.

c Early and Late diets: 4\% alfalfa hay, 4\% permanent grassland hay, 3\% alfalfa haylage; TMR diet: 6\% alfalfa hay, 6\% permanent grassland hay, 4\% alfalfa haylage.

d Early and Late diets: $13 \%$ corn flour, $2 \%$ barley flakes, $7 \%$ soybean meal; TMR diet: $17 \%$ corn flour, $2 \%$ barley flakes, $9 \%$ soybean meal.

e TMR starch content $=28.3 \mathrm{~g} / 100 \mathrm{~g}$ of DM. 
Table 3

Herd characteristics, diet composition, and fresh herbage nutritive value according to the fresh herbage phenological stage and proportions in cow diet in the commercial farms involved in the survey.

\begin{tabular}{|c|c|c|c|c|c|c|}
\hline \multirow[t]{2}{*}{ Item $^{a}$} & \multicolumn{2}{|l|}{ Low } & \multicolumn{2}{|c|}{ Intermediate } & \multicolumn{2}{|c|}{ Full grazing } \\
\hline & Early & Late & Early & Late & Early & Late \\
\hline No. of samples & 9 & 8 & 14 & 7 & 8 & 14 \\
\hline No. of cows/farm & 84 & 72 & 22 & 21 & 28 & 30 \\
\hline \multicolumn{7}{|l|}{ Breed (\% of farms in the group) } \\
\hline Holstein & 70.0 & 71.4 & - & - & - & - \\
\hline Piemontese & - & - & 13.3 & 57.1 & 50.0 & 21.4 \\
\hline Valdostana Red Pied & - & - & 73.3 & 28.6 & 12.5 & 28.6 \\
\hline Italian Red Pied & - & - & 6.7 & 14.3 & - & 7.2 \\
\hline Barà-Pustertaler & - & - & - & - & 12.5 & 21.4 \\
\hline Crossbreeds & 30.0 & 28.6 & 6.7 & - & 25.0 & 21.4 \\
\hline Altitude (m a.s.l.) & 247 & 253 & 793 & 615 & 1811 & 1869 \\
\hline Farm with upland pasture (\%) & - & - & 33.3 & 14.3 & 87.5 & 78.6 \\
\hline \multicolumn{7}{|l|}{ Diet composition (\% on DM) } \\
\hline Fresh herbage & 21.1 & 17.1 & 71.4 & 73.5 & 100 & 100 \\
\hline Hay & 26.6 & 22.9 & 15.7 & 18.2 & - & - \\
\hline Corn silage & 15.7 & 23.6 & 0.3 & - & - & - \\
\hline Concentrates & 36.6 & 36.4 & 12.6 & 8.3 & - & - \\
\hline \multicolumn{7}{|l|}{ Fresh herbage nutritive value } \\
\hline DM (\%) & 21.6 & 22.0 & 23.5 & 25.4 & 30.1 & 33.6 \\
\hline NDF (g/100 g DM) & 45.4 & 47.5 & 48.9 & 50.7 & 50.2 & 53.4 \\
\hline $\mathrm{ADF}(\mathrm{g} / 100 \mathrm{~g} \mathrm{DM})$ & 24.6 & 28.8 & 31.5 & 31.8 & 30.1 & 31.7 \\
\hline $\mathrm{CP}(\mathrm{g} / 100 \mathrm{~g} \mathrm{DM})$ & 17.1 & 15.7 & 14.0 & 12.6 & 14.9 & 12.3 \\
\hline OMD (\%) & 77.5 & 68.8 & 73.3 & 69.0 & 69.7 & 67.9 \\
\hline
\end{tabular}

a Low, low fresh herbage proportions in cow diet (20\% of DM); Intermediate, intermediate fresh herbage proportion in cow diet (75\% of DM); Early, from grasses steam elongation to booting; Late, from grasses heading to flowering; DM, dry matter; NDF, neutral detergent fiber; ADF, acid detergent fiber; CP, crude protein; OMD, organic matter digestibility.

experimental plots. The Low fresh herbage group of farms mainly rear Holstein cows and crossbreeds (i.e. Holstein $\times$ Belgian Blue, or Holstein $\times$ Piemontese), whereas the farms in the Intermediate fresh herbage proportion and Full grazing groups, mainly rear double purpose local breeds, such as Valdostana Red Pied, Italian Red Pied, Piemontese, Barà-Pustertaler, and several crossbreeds, including crossbreeds with Holstein cows.

\subsection{Cow performance}

The milk yield decreased with the development of herbage phenological stage for all pasture types in Experiment 1 (Table 4) and in Experiment 2 (Table 5). The milk protein content decreased with herbage maturity in Experiment 2 (Table 5). In Experiment 3, the cows fed TMR plus herbage at a late phenological stage produced less milk than those fed TMR plus herbage at an earlier phenological stage or only TMR (Table 6). Cows from the Early or TMR groups had a lower milk protein content than the Late group (Table 6). On the other hand, when operating in on-farm conditions (Experiment 4 ), no differences in dairy performance were observed on the basis of the herbage phenology (Table 7), but the milk yield was significantly higher in the farms of Low fresh herbage proportion group.

\subsection{Milk FA composition}

\subsubsection{Experiment 1: Full grazing}

The even chain saturated FA (ECSFA) were generally stable during the experiment, except for the highly biodiversified pasture groups, for which they decreased when herbage was grazed at a late stage. However, the milk C16:0 concentration increased with herbage maturity for all groups, while the C18:0 concentration decreased (Table 4; Fig. 2). The sum of the de novo synthesized FA decreased on average with the development of herbage phenology. The odd chain FA (OCFA) and branched-chain FA(BCFA) increased when cows grazed on mature herbage, except for the highly biodiversified pasture group, for which the BCFA concentration did not differ. As far as the monounsaturated FA (MUFA) are concerned, the concentrations of C18:1c9 and the total C18:1cis isomers generally increased in the milk from highly biodiversified pasture group, as the herbage phenology proceeded. On the contrary, the C18:1t11, and total C18:1trans isomers concentrations decreased as the herbage phenology developed for the three groups (Table 4; Fig. 2), but the decrease tended to be more noticeable for the highly biodiversified pasture. The CLAC9t11 and the total PUFA concentrations followed the same trend as C18:1t11 (Table 4; Fig. 2). The milk C18:2n-6 concentration was higher when cows grazed on herbage at a late phenological stage rather than at an earlier one for the highly biodiversified pasture group, but was stable for the other groups. The $\mathrm{C} 18: 3 n-3$ concentration decreased with herbage maturity for the three groups, whereas the $n-6$ FA to $n-3$ FA ratio did not differ among periods for the temporary grassland and the moderately diversified pasture, but increased with the development of 
Table 4

Experiment 1 - Full grazing: changes in milk yield and composition from the three pasture types according to herbage phenology.

\begin{tabular}{|c|c|c|c|c|c|c|c|c|c|c|}
\hline \multirow[t]{2}{*}{ Item $^{A}$} & \multicolumn{2}{|c|}{$\begin{array}{l}\text { Temporary } \\
\text { grassland }\end{array}$} & \multicolumn{2}{|c|}{$\begin{array}{l}\text { Moderately } \\
\text { biodiversified } \\
\text { pasture }\end{array}$} & \multicolumn{2}{|c|}{$\begin{array}{l}\text { Highly } \\
\text { biodiversified } \\
\text { pasture }\end{array}$} & \multirow[t]{2}{*}{ SEM } & \multicolumn{3}{|c|}{ Effects and significance ${ }^{B}$} \\
\hline & Early & Late & Early & Late & Early & Late & & Pasture type & Phenology & Interaction \\
\hline Milk yield $(\mathrm{kg} / \mathrm{cow} \times$ day $)$ & $18.2^{\mathrm{ab}}$ & $14.3^{\mathrm{cd}}$ & $20.3^{a}$ & $15.5^{\mathrm{bc}}$ & $15.6^{\mathrm{bc}}$ & $12.3^{\mathrm{d}}$ & 0.38 & $* *$ & $* * *$ & * \\
\hline Fat ( $\mathrm{g} / \mathrm{kg}$ of milk) & 36.3 & 38.1 & 37.2 & 36.8 & 38.9 & 37.6 & 0.43 & ns & ns & ns \\
\hline Protein (g/kg of milk) & 32.5 & 32.2 & 32.9 & 32.5 & 30.5 & 30.0 & 0.21 & $* *$ & ns & ns \\
\hline \multicolumn{11}{|l|}{ Fatty acid (g/100 g FA) } \\
\hline$\sum$ de novo FA & 25.65 & 24.79 & 28.81 & 26.87 & 21.04 & 20.41 & 0.465 & $* * *$ & $*$ & ns \\
\hline C16:0 & 21.76 & 24.51 & 23.14 & 25.77 & 23.53 & 25.22 & 0.236 & ns & $* * *$ & ns \\
\hline C18:0 & $8.47^{b c}$ & $8.04^{c}$ & $8.20^{c}$ & $8.68^{\mathrm{b}}$ & $10.38^{\mathrm{a}}$ & $8.05^{\mathrm{c}}$ & 0.212 & ns & $* *$ & $* * *$ \\
\hline C18:1t10 & 0.32 & 0.28 & 0.34 & 0.26 & 0.36 & 0.26 & 0.013 & ns & $*$ & ns \\
\hline C18:1t11 & $3.49^{\mathrm{b}}$ & $2.77^{c}$ & $3.64^{\mathrm{a}}$ & $2.59^{c}$ & $3.62^{\mathrm{a}}$ & $1.99^{\mathrm{d}}$ & 0.125 & ns & $* * *$ & $*$ \\
\hline $\mathrm{C} 18: 1 \mathrm{c} 9$ & $21.95^{\mathrm{bc}}$ & $21.39^{b c}$ & $18.63^{d}$ & $19.09^{\text {cd }}$ & $23.36^{\mathrm{b}}$ & $26.36^{\mathrm{a}}$ & 0.423 & $* *$ & $*$ & $* *$ \\
\hline$C 18: 2 n-6$ & $0.92^{\mathrm{bc}}$ & $0.79^{c}$ & $0.77^{c}$ & $0.77^{\mathrm{c}}$ & $1.09^{\mathrm{b}}$ & $1.29^{\mathrm{a}}$ & 0.028 & $* * *$ & ns & $* * *$ \\
\hline$C 18: 3 n-3$ & 0.67 & 0.59 & 0.60 & 0.58 & 0.80 & 0.77 & 0.019 & $*$ & $* * *$ & ns \\
\hline CLAc9t11 & 2.09 & 1.80 & 2.11 & 1.42 & 1.69 & 1.26 & 0.083 & ns & $* * *$ & ns \\
\hline ECSFA & $56.04^{\mathrm{bc}}$ & $57.54^{\mathrm{bc}}$ & $60.29^{\mathrm{ab}}$ & $61.53^{\mathrm{a}}$ & $55.23^{\mathrm{c}}$ & $53.91^{\mathrm{d}}$ & 0.497 & $* *$ & ns & $*$ \\
\hline OCFA & 2.38 & 2.83 & 2.26 & 2.59 & 2.37 & 2.68 & 0.033 & ns & $* * *$ & ns \\
\hline BCFA & $2.49^{\mathrm{b}}$ & $2.75^{\mathrm{a}}$ & $2.36^{\mathrm{c}}$ & $2.67^{\mathrm{ab}}$ & $2.41^{\mathrm{bc}}$ & $2.40^{\mathrm{bc}}$ & 0.032 & ns & $* * *$ & $* *$ \\
\hline MUFA & $31.64^{\mathrm{b}}$ & $30.06^{c}$ & $28.35^{\mathrm{cd}}$ & $27.24^{\mathrm{d}}$ & $33.07^{\mathrm{ab}}$ & $34.65^{\mathrm{a}}$ & 0.449 & $* *$ & ns & $* *$ \\
\hline PUFA & 4.77 & 4.14 & 4.35 & 3.61 & 4.61 & 4.15 & 0.083 & ns & $* * *$ & ns \\
\hline$\Sigma C 18: 1 \mathrm{t}$ & 5.21 & 4.15 & 5.23 & 3.90 & 5.23 & 3.16 & 0.137 & ns & $* * *$ & $\dagger$ \\
\hline$\Sigma \mathrm{C} 18: 1 \mathrm{c}$ & $23.11^{\mathrm{bc}}$ & $22.47^{\mathrm{bc}}$ & $19.58^{\mathrm{d}}$ & $20.04^{\mathrm{d}}$ & $24.72^{\mathrm{b}}$ & $27.74^{\mathrm{a}}$ & 0.447 & $* *$ & $*$ & $* *$ \\
\hline$n-6 / n-3$ & $1.41^{\mathrm{ab}}$ & $1.42^{\mathrm{ab}}$ & $1.37^{\mathrm{ab}}$ & $1.35^{\mathrm{b}}$ & $1.32^{\mathrm{b}}$ & $1.67^{\mathrm{a}}$ & 0.027 & ns & $* *$ & $* *$ \\
\hline $\mathrm{C} 14: 1 \mathrm{c} 9 / \mathrm{C} 14: 0$ & 0.082 & 0.085 & 0.093 & 0.083 & 0.076 & 0.083 & 0.001 & ns & ns & ns \\
\hline $\mathrm{C} 18: 1 \mathrm{c} 9 / \mathrm{C} 16: 0$ & $1.02^{\mathrm{a}}$ & $0.88^{\mathrm{b}}$ & $0.81^{\mathrm{c}}$ & $0.75^{\mathrm{d}}$ & $1.00^{\mathrm{ab}}$ & $1.05^{\mathrm{a}}$ & 0.023 & $*$ & $\dagger$ & $* *$ \\
\hline
\end{tabular}

A Early, grasses between stem elongation and booting; Late, grasses between heading and flowering; de novo FA, sum of de novo synthetized FA; ECSFA, sum of even-chain saturated FA; OCFA, sum of odd-chain FA; BCFA, sum of branched-chain FA; MUFA, sum of monounsaturated FA; PUFA, sum of polyunsaturated FA.

B ${ }^{* * *} P<0.001 ;{ }^{* *} P<0.01 ;{ }^{*} P<0.05 ;{ }^{\dagger} P<0.1 ;$ ns $=$ not significant; different superscript letters within the same row indicate differences among pasture types and herbage phenology.

Table 5

Experiment 2 - Intermediate fresh herbage proportion in cow diet: changes in milk yield and composition according to herbage phenology.

\begin{tabular}{|c|c|c|c|c|}
\hline Item $^{\mathrm{a}}$ & Early & Late & SEM & Significance ${ }^{\mathrm{b}}$ \\
\hline Milk yield $(\mathrm{kg} / \mathrm{cow} \times$ day $)$ & 22.97 & 15.77 & 0.990 & * \\
\hline Fat ( $\mathrm{g} / \mathrm{kg}$ of milk) & 36.91 & 38.12 & 1.185 & ns \\
\hline Protein (g/kg of milk) & 31.95 & 30.34 & 0.609 & $\dagger$ \\
\hline \multicolumn{5}{|l|}{ Fatty acid (g/100g FA) } \\
\hline$\Sigma$ de novo $\mathrm{FA}$ & 23.13 & 22.29 & 0.370 & ns \\
\hline C16:0 & 24.45 & 26.65 & 0.355 & * \\
\hline C18:0 & 10.03 & 10.64 & 0.348 & ns \\
\hline C18:1t10 & 0.47 & 0.28 & 0.026 & * \\
\hline C18:1t11 & 2.96 & 1.88 & 0.136 & $* *$ \\
\hline C18:1c9 & 23.41 & 23.82 & 0.433 & ns \\
\hline$C 18: 2 n-6$ & 1.19 & 1.13 & 0.039 & $\mathrm{~ns}$ \\
\hline$C 18: 3 n-3$ & 0.68 & 0.59 & 0.019 & $*$ \\
\hline CLAc9t11 & 1.38 & 0.86 & 0.084 & * \\
\hline ECSFA & 57.80 & 59.86 & 0.411 & $\dagger$ \\
\hline OCFA & 2.30 & 2.28 & 0.031 & ns \\
\hline BCFA & 2.15 & 2.07 & 0.046 & ns \\
\hline MUFA & 31.98 & 30.71 & 0.389 & $\mathrm{~ns}$ \\
\hline PUFA & 4.03 & 3.25 & 0.125 & $*$ \\
\hline$\Sigma C 18: 1 \mathrm{t}$ & 4.66 & 3.15 & 0.181 & ** \\
\hline$\Sigma \mathrm{C} 18 \mathrm{:} 1 \mathrm{c}$ & 24.27 & 24.57 & 0.439 & ns \\
\hline$n-6 / n-3$ & 1.55 & 1.66 & 0.060 & ns \\
\hline $\mathrm{C} 14: 1 \mathrm{c} 9 / \mathrm{C} 14: 0$ & 0.07 & 0.07 & 0.001 & $\mathrm{~ns}$ \\
\hline C18:1c9/C16:0 & 0.96 & 0.90 & 0.025 & * \\
\hline
\end{tabular}

a Early, grasses between stem elongation and booting; Late, grasses between heading and flowering; de novo FA, sum of de novo synthetized FA; ECSFA, sum of even-chain saturated FA; OCFA, sum of odd-chain FA; BCFA, sum of branched-chain FA; MUFA, sum of monounsaturated FA; PUFA, sum of polyunsaturated FA.

b ${ }^{* *} P<0.01 ;{ }^{*} P<0.05 ;{ }^{\dagger} P<0.1 ;$ ns $=$ not significant. 
Table 6

Experiment 3 - Low fresh herbage proportion in cow diet: milk yield and composition according to the herbage phenological stage in comparison to total mixed ration (TMR).

\begin{tabular}{|c|c|c|c|c|c|}
\hline Item $^{A}$ & Early & Late & TMR & SEM & Significance $^{B}$ \\
\hline Mill yield (kg/cow $\times$ day) & $30.4^{\mathrm{a}}$ & $28.0^{\mathrm{b}}$ & $31.6^{\mathrm{a}}$ & 0.75 & ** \\
\hline Fat (g/kg of milk) & 36.9 & 35.8 & 35.4 & 0.79 & ns \\
\hline Protein (g/kg of milk) & $33.4^{\mathrm{a}}$ & $31.6^{\mathrm{b}}$ & $33.4^{\mathrm{a}}$ & 0.40 & $* * *$ \\
\hline \multicolumn{6}{|l|}{ Fatty acid (g/100 g FA) } \\
\hline$\sum$ de novo $\mathrm{FA}$ & $20.36^{\mathrm{b}}$ & $21.28^{\mathrm{b}}$ & $22.23^{\mathrm{a}}$ & 0.346 & * \\
\hline $\mathrm{C} 16: 0$ & $27.31^{\mathrm{b}}$ & $28.64^{\mathrm{a}}$ & $29.08^{\mathrm{a}}$ & 0.318 & $* * *$ \\
\hline C18:0 & 10.59 & 10.36 & 10.39 & 0.174 & ns \\
\hline $\mathrm{C} 18: 1 \mathrm{t} 10$ & $0.39^{\mathrm{b}}$ & $0.62^{\mathrm{a}}$ & $0.46^{\mathrm{b}}$ & 0.023 & $* * *$ \\
\hline C18:1t11 & $1.47^{\mathrm{a}}$ & $1.39^{\mathrm{a}}$ & $1.05^{\mathrm{b}}$ & 0.060 & $* * *$ \\
\hline C18:1c9 & $23.18^{a}$ & $20.70^{\mathrm{b}}$ & $20.72^{\mathrm{b}}$ & 0.411 & $*$ \\
\hline$C 18: 2 n-6$ & $2.19^{\mathrm{b}}$ & $2.66^{\mathrm{a}}$ & $2.50^{\mathrm{a}}$ & 0.068 & $* * *$ \\
\hline$C 18: 3 n-3$ & $0.41^{\mathrm{a}}$ & $0.37^{\mathrm{b}}$ & $0.31^{\mathrm{c}}$ & 0.010 & $* * *$ \\
\hline CLAc9t11 & $0.69^{\mathrm{a}}$ & $0.65^{\mathrm{a}}$ & $0.55^{\mathrm{b}}$ & 0.021 & $* * *$ \\
\hline ECSFA & $58.61^{\mathrm{b}}$ & $60.64^{\mathrm{b}}$ & $62.04^{\mathrm{a}}$ & 0.540 & $* *$ \\
\hline OCFA & $2.20^{\mathrm{a}}$ & $1.92^{\mathrm{b}}$ & $1.97^{\mathrm{b}}$ & 0.030 & $*$ \\
\hline BCFA & $2.06^{\mathrm{a}}$ & $1.77^{\mathrm{b}}$ & $1.69^{\mathrm{b}}$ & 0.036 & $* * *$ \\
\hline MUFA & $31.59^{a}$ & $29.78^{\mathrm{ab}}$ & $28.91^{\mathrm{b}}$ & 0.466 & $* *$ \\
\hline PUFA & $4.70^{\mathrm{ab}}$ & $5.07^{\mathrm{a}}$ & $4.60^{\mathrm{b}}$ & 0.088 & $* *$ \\
\hline$\Sigma C 18: 1 \mathrm{t}$ & $3.14^{\mathrm{ab}}$ & $3.61^{\mathrm{a}}$ & $2.94^{\mathrm{b}}$ & 0.104 & $* *$ \\
\hline$\Sigma \mathrm{C} 18: 1 \mathrm{c}$ & $24.96^{\mathrm{a}}$ & $22.70^{\mathrm{b}}$ & $22.62^{\mathrm{b}}$ & 0.426 & $*$ \\
\hline$n-6 / n-3$ & $4.67^{\mathrm{b}}$ & $6.09^{\mathrm{a}}$ & $6.51^{\mathrm{a}}$ & 0.186 & $* * *$ \\
\hline $\mathrm{C} 14: 1 \mathrm{c} 9 / \mathrm{C} 14: 0$ & 0.085 & 0.086 & 0.087 & 0.002 & ns \\
\hline C18:1c9/C16:0 & $0.85^{\mathrm{a}}$ & $0.73^{\mathrm{b}}$ & $0.72^{\mathrm{b}}$ & 0.023 & $*$ \\
\hline
\end{tabular}

A Early, grasses stem elongation; Late, grasses flowering; de novo FA, sum of de novo synthetized FA; ECSFA, sum of even-chain saturated FA; OCFA, sum of odd-chain FA; BCFA, sum of branched-chain FA; MUFA, sum of monounsaturated FA; PUFA, sum of polyunsaturated FA.

B ${ }^{* * *} P<0.001 ;{ }^{* *} P<0.01 ;{ }^{*} P<0.05 ;$ ns = not significant; different superscript letters within the same row indicate differences among treatments.

Table 7

Experiment 4 - Survey on farm: milk yield and composition according to the fresh herbage phenology and proportion in cow diet.

\begin{tabular}{|c|c|c|c|c|c|c|c|c|c|c|}
\hline \multirow[t]{2}{*}{ Item $^{A}$} & \multicolumn{2}{|l|}{ Low } & \multicolumn{2}{|c|}{ Intermediate } & \multicolumn{2}{|c|}{ Full grazing } & \multirow[t]{2}{*}{ SEM } & \multicolumn{3}{|c|}{ Effect and significance $^{B}$} \\
\hline & Early & Late & Early & Late & Early & Late & & $\begin{array}{l}\text { Fresh herbage } \\
\text { proportion }\end{array}$ & Phenology & Interaction \\
\hline Milk yield (kg/cow × day) & 22.0 & 23.3 & 9.1 & 7.3 & 7.5 & 6.8 & 1.1 & $* * *$ & ns & ns \\
\hline Fat (g/kg of milk) & 37.9 & 38.5 & 37.5 & 37.6 & 40.7 & 38.9 & 0.41 & ns & ns & ns \\
\hline Protein (g/kg of milk) & 33.7 & 33.9 & 33.4 & 33.5 & 34.6 & 34.3 & 0.31 & ns & ns & ns \\
\hline \multicolumn{11}{|l|}{ Fatty acids (g/100 g FA) } \\
\hline$\sum$ de novo $\mathrm{FA}$ & 23.45 & 23.67 & 19.61 & 20.09 & 18.96 & 17.57 & 0.377 & $* * *$ & ns & ns \\
\hline C16:0 & 29.04 & 29.81 & 24.17 & 23.56 & 22.55 & 22.15 & 0.478 & $* * *$ & ns & ns \\
\hline C18:0 & 9.74 & 9.66 & 10.36 & 11.58 & 10.76 & 11.29 & 0.193 & $*$ & $*$ & $\dagger$ \\
\hline C18:1t10 & 0.29 & 0.29 & 0.27 & 0.25 & 0.30 & 0.26 & 0.006 & ns & ns & ns \\
\hline C18:1t11 & $1.14^{\mathrm{d}}$ & $1.09^{\mathrm{d}}$ & $3.35^{\mathrm{b}}$ & $2.43^{c}$ & $4.61^{\mathrm{a}}$ & $3.63^{\mathrm{b}}$ & 0.174 & $* * *$ & $* * *$ & $*$ \\
\hline C18:1c9 & 19.90 & 19.26 & 22.87 & 22.88 & 21.37 & 24.18 & 0.391 & $* *$ & ns & $\dagger$ \\
\hline$C 18: 2 n-6$ & 1.96 & 1.87 & 1.40 & 1.53 & 1.53 & 1.60 & 0.051 & $* *$ & ns & ns \\
\hline$C 18: 3 n-3$ & 0.61 & 0.55 & 1.06 & 1.14 & 1.45 & 1.37 & 0.051 & $* * *$ & ns & ns \\
\hline CLAc9t11 & $0.55^{\mathrm{d}}$ & $0.51^{\mathrm{d}}$ & $1.72^{\mathrm{b}}$ & $1.11^{\mathrm{c}}$ & $2.14^{\mathrm{a}}$ & $1.67^{\mathrm{b}}$ & 0.082 & $* * *$ & $* * *$ & $*$ \\
\hline ECSFA & 62.50 & 63.40 & 54.44 & 55.58 & 52.62 & 51.40 & 0.697 & $* * *$ & ns & ns \\
\hline OCFA & 2.21 & 2.13 & 2.77 & 3.01 & 3.03 & 3.13 & 0.067 & $* * *$ & ns & ns \\
\hline BCFA & 2.08 & 1.97 & 2.77 & 2.81 & 3.07 & 2.92 & 0.071 & $* * *$ & ns & ns \\
\hline MUFA & 27.82 & 27.28 & 33.10 & 32.12 & 32.78 & 34.82 & 0.491 & $* * *$ & ns & ns \\
\hline PUFA & 4.49 & 4.31 & 5.97 & 5.69 & 7.59 & 6.83 & 0.167 & $* * *$ & $*$ & $\dagger$ \\
\hline$\Sigma \mathrm{C} 18: 1 \mathrm{t}$ & $2.54^{\mathrm{d}}$ & $2.52^{\mathrm{d}}$ & $4.86^{\mathrm{b}}$ & $3.87^{c}$ & $6.16^{\mathrm{a}}$ & $5.17^{\mathrm{b}}$ & 0.186 & $* * *$ & $* *$ & $*$ \\
\hline$\Sigma \mathrm{C} 18: 1 \mathrm{c}$ & 21.58 & 21.02 & 24.68 & 24.84 & 23.24 & 26.20 & 0.409 & $* *$ & ns & $\dagger$ \\
\hline$n-6 / n-3$ & 2.91 & 2.99 & 1.25 & 1.30 & 1.03 & 1.13 & 0.121 & $* * *$ & ns & ns \\
\hline $\mathrm{C} 14: 1 \mathrm{c} 9 / \mathrm{C} 14: 0$ & 0.092 & 0.092 & 0.089 & 0.080 & 0.070 & 0.077 & 0.002 & $* * *$ & ns & ns \\
\hline C18:1c9/C16:0 & 0.71 & 0.66 & 0.96 & 0.98 & 0.95 & 1.09 & 0.028 & $* * *$ & ns & ns \\
\hline
\end{tabular}

A Low, low fresh herbage proportions in cow diet (20\% of DM); Intermediate, intermediate fresh herbage proportion in cow diet (75\% of DM); Early, from grasses steam elongation to booting; Late, from grasses heading to flowering; de novo FA, sum of de novo synthetized FA; ECSFA, sum of even-chain saturated FA; OCFA, sum of odd-chain FA; BCFA, sum of branched-chain FA; MUFA, sum of monounsaturated FA; PUFA, sum of polyunsaturated FA.

B ${ }^{* * *} P<0.001 ;{ }^{* *} P<0.01 ;{ }^{*} P<0.05 ;{ }^{\dagger} P<0.1$; ns = not significant; different superscript letters within the same row indicate differences among treatments. 

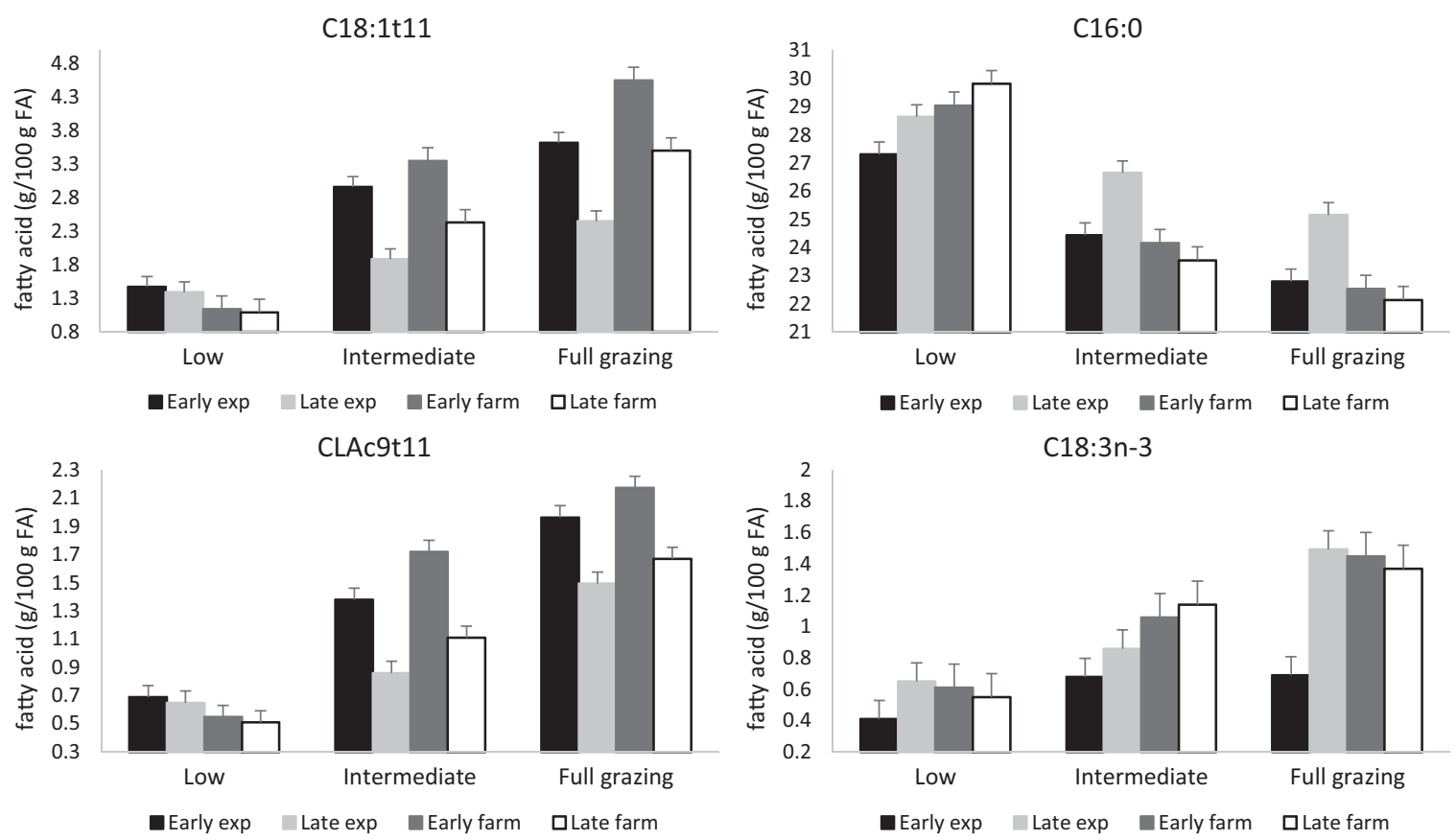

Fig. 2. Effect of herbage phenological stage on milk FA concentrations at increasing fresh herbage proportion in cow diet: comparison of results found in controlled conditions and on farm. Note: Low, low fresh herbage proportions in cow diet; Intermediate, intermediate fresh herbage proportions in cow diet; Early, from grasses steam elongation to booting; Late, from grasses heading to flowering.

herbage phenology in the highly biodiversified pasture. The C18:1c9 to C16 ratio decreased in the temporary grassland and moderately diversified pasture milk during the experiment, but was stable in the highly biodiversified pasture milk.

\subsubsection{Experiment. 2: Intermediate fresh herbage proportion}

The milk C16:0 concentration increased as the herbage phenology developed (Table 5; Fig. 2). The same trend was observed numerically $(P<0.10)$ for the ECSFA concentration. The C18:1t10, C18:1t11, total C18:1trans isomers, CLAc9t11, and total PUFA concentrations decreased as the herbage phenology developed. On the other hand, no significant differences were observed for $\mathrm{C} 18: 1 \mathrm{c} 9$ and total $\mathrm{C} 18: 1 \mathrm{cis}$ isomers on the basis of the phenological stage of grazed herbage. The milk C18:3n-3 concentration decreased as the herbage phenology developed (Table 5; Fig. 2). The C18:2n-6, and the $n-6$ FA to $n-3$ FA ratio remained stable, whereas the C18:1c9 to C16:0 ratio decreased with herbage grazed at a late phenological stage.

\subsubsection{Experiment 3: Low fresh herbage proportion}

The milk C16:0 concentration of the Early group was lower than those of the other groups (Table 6; Fig. 2). The Early group produced milk with higher concentrations of C18:1c9, total C18:1cis isomers, OCFA, and BCFA, as well as a higher C18:1c9 to C16:0 ratio, but with a lower C18:2n-6 concentration and a lower $n-6$ FA to $n-3$ FA ratio than the Late and TMR groups, which did not differ from each other as far as the concentrations of these FA are concerned. The C18:3n-3 concentration was the highest in the Early milk, and the lowest in the TMR milk (Table 6). The milk from the Late group also had a higher concentration of C18:1t10 than the other groups. The milk from Early and Late groups did not differ as far as the C18:1t11 and CLAc9t11 concentrations are concerned, as both were higher than in the TMR milk.

\subsubsection{Experiment 4: On-farm survey}

The groups of farms with different fresh herbage proportion were associated with changes in almost all the milk FA concentrations (Table 7). The concentrations of saturated FA (except for C18:0) and the C18:2n-6, and the $n-6$ FA to $n-3$ FA ratio decreased, whereas all the other FA concentrations increased with increasing fresh herbage proportions in the cow diet. Only C18:0, C18:1t11, CLAc9t11, the sum of the C18:1trans isomers, and the total PUFA concentrations varied according to herbage phenological stage (Table 7). Their concentrations in the Early and Late milk did not differ within the Low fresh herbage group. However, in the Intermediate fresh herbage group, the concentration of C18:0 (-1.22 g/100 g FA) was lower, while the concentrations of C18:1t11, CLAc9t11, and the sum of the C18:1trans isomers were higher for Early milk than for Late milk ( $+0.92,+0.51$, and $+0.99 \mathrm{~g} / 100 \mathrm{~g}$ FA, respectively) (Table 7$)$. A similar trend was also observed in the Full grazing groups: $-0.53 ;+0.98,+0.47$, and $+0.99 \mathrm{~g} / 100 \mathrm{~g}$ FA for C18:0, C18:1t11, CLAc9t11, and for the sum of C18:1trans isomers, respectively (Table 7). The concentrations of these FA of the Late Full grazing milk were similar to those of the Early 
Intermediate fresh herbage milk (Table 7; Fig. 2). The concentration of C18:1c9 and of the sum of C18:1cis isomers tended to be higher $(P<0.10)$ in cows grazing on herbage at a late phenological stage than at an earlier one, when cows grazed fresh herbage only ( +2.81 and $+3.04 \mathrm{~g} / 100 \mathrm{~g}$ FA, respectively) (Table 7 ).

\section{Discussion}

\subsection{Effect of herbage phenology on milk fatty acid composition in controlled conditions}

The experiments carried out in controlled conditions have highlighted an overall effect of herbage phenological stage on milk yield and FA composition (Fig. 2). As expected, milk yield decreased as the herbage nutritive value decreased, due to the development of herbage phenological stage. The higher the proportion of fresh herbage in cow diet, the higher the number of groups or individual FA that were affected by herbage phenological stage. When fresh herbage was the main ingredient in a cow diet, an increase in the C16:0 concentration was observed with the development of the herbage phenology (Fig. 2). Similar finding were observed by Cabiddu et al. (2005) for ewe milk. The increase in milk C16:0 concentration can be related to the increase in C16:0 concentration in herbage during maturation (Glasser et al., 2013; Revello-Chion et al., 2011), as about half of the C16:0 in the milk is derived directly from dietary C16:0 (Chilliard et al., 2007). Mature herbage is characterized by lower readily degradable fiber content and higher undegradable fiber content (Revello-Chion et al., 2011), which could result in a lower production of rumen volatile FA, which is used as a substrate for the de novo synthesis of FA in the mammary gland (Chilliard et al., 2007). This hypothesis is consistent with the lower concentration of de novo synthesis FA concentration in the milk produced from herbage grazed at late phenological stage compared to earlier stage. The OCFA and BCFA concentrations in milk, that originate from the ruminal bacteria population, depend on the fiber content of the diets (Dewhurst et al., 2006; Vlaemink et al., 2006). Thus, the increase observed in OCFA and BCFA concentrations in milk with herbage phenology development is consistent with the concomitant rise in the aNDF and ADF contents of the herbage (Revello-Chion et al., 2011). This result has already been observed by Kälber et al. (2014) who fed different pure forage species to dairy cows. This increase in milk OCFA and BCFA concentrations with the herbage phenology was not observed when fresh herbage was integrated with other feeds rich in fiber, such as hay, in cow diet. In the present study, the milk derived from fresh herbage at an earlier phenological stage had higher concentrations of C18:1t11 and CLAc9t11, than those derived from mature herbage (Fig. 2), a result that is in agreement with the findings of Vanhatalo et al. (2007) and Cabiddu et al. (2005). When herbage matures, its fat content and C18:3n-3 concentration decreases (Coppa et al., 2015; Glasser et al., 2013; Revello-Chion et al., 2011), and results in a lower intake of this FA when cows are grazed on herbage at a late phenology, thus confirming that C18:1t11 is an intermediate product of dietary PUFA biohydrogenation (in particular of C18:3n - 3) in the rumen (Chilliard et al., 2007). A similar explanation could be also given for the decrease in the total PUFA concentration in milk observed as the herbage phenology developed. However, Kälber et al. (2014) observed an increasing trend in C18:1t11 and CLAc9t11 in cows fed fresh cut buckwheat, chicory and phacelia, species, which were selected because of their high plant secondary metabolites content. The effect of herbage phenology on milk FA composition was found to be different for the different forage species, on the basis of the different evolutions of the plant secondary metabolites or enzymes contents (i.e. polyphenol-oxidase) during maturation (Kälber et al., 2014; Cabiddu et al., 2005, 2010). The plant secondary metabolites and polyphenol-oxidase could interact with ruminal biohydrogenation and lipolysis that affected the concentration of $\mathrm{C} 18: 3 n-3$ and its biohydrogenation intermediate products in the milk (Kälber et al., 2014; Cabiddu et al., 2010; Leiber et al., 2005). This hypothesis could also explain the contradicting decreasing trend in the C18:3n-3 concentration in milk when mature herbage was fed to cows as observed in our study and by Kälber et al. (2014), in contrast to the increasing trend observed by Cabiddu et al. (2005) feeding Mediterranean species to sheep. However, in the present experiments, the effects of herbage phenology on the FA composition of milk were similar, regardless of the herbage botanical composition, except for C18:1c9 and C18:2n-6, whose concentrations were higher in the late than in early highly biodiversified pasture milk, and BCFA, whose concentration did not differ according to the highly biodiversified pasture phenological stage. This result is in agreement with previous findings in similar conditions (Coppa et al., 2011, 2015). These results could be related to the dominance of grasses (poor in plant secondary metabolites) in the natural or artificial grasslands in the experimental plots.

An original finding of the present study is the key role played by the phenological stage of the fresh herbage, even when low proportions of fresh herbage were offered to cows. In fact, when about $25 \%$ of dietary DM of mature herbage was fed to cows, the FA profile of derived milk only differed for the higher concentrations of C18:1t11, CLAc9t11, and C18:3n-3 from the control TMR diet. On the contrary, when cows were fed with a similar proportion of fresh herbage at an earlier phenological stage, a decrease in the C16:0 and C18:2n-6 concentrations, and in the $n-6$ FA to $n-3$ FA ratio, as well as an increase in the C18:1c9, C18:3n - 3, OCFA, and BCFA concentrations, and the C18:1c9 to C16:0 ratio were observed in milk compared to both the control TMR and the Late milk. Multiple sources of dietary FA (i.e. corn silage and concentrates, which are rich in C18:2n-6 or C16:0; Chilliard et al., 2007) were present in the low herbage proportion diet, that could have affected ruminal biohydrogenation pathways and FA synthesis in the mammary gland. The higher lipid content and C18:3n-3 concentration in the herbage at an early phenological stage, compared to mature herbage (Coppa et al., 2015; Revello-Chion et al., 2011; Elgersma et al., 2006), seemed to be sufficient to change the ruminal environment so that it had an important impact on milk FA composition. However, this did not happen for the fresh herbage at a late phenological stage. 


\subsection{Effect of farming system characterized by different fresh herbage proportions}

In Experiment 4, the groups of farms defined on the basis of the fresh herbage proportion in the cow diet corresponded to different farming systems. As a consequence, it is not possible to rule out that other factors related to the farming system, such as breed, may have concurred in determining the differences in the FA composition of milk between the groups of farms. Indeed, the farms belonging to the Low group reared high yielding breeds (manly Holstein cows), compared to the various double purpose and low yielding breeds that were reared indifferently in the Intermediate and Full grazing groups. An effect of cow breed on the FA composition of milk has been shown by several authors in controlled conditions, but has generally resulted to be minimal compared to the effect of the feeding system, and has mainly been limited to the FA related to the $\Delta-9$ desaturase activity or to the lipolytic system (Ferlay et al., 2006, 2010; Hurtaud et al., 2009). Furthermore, the effects of breed and of all the animal related factors were found to be negligible in determining the FA composition of a large number of bulk milks collected from commercial farms at a European scale (Coppa et al., 2013). Therefore, the differences observed according to the groups of farms could be more likely due to the combined influence of the proportion of fresh herbage in the diet and of the botanical composition of the fresh herbage that was grazed. Indeed, the Low group was composed of farms whose herds mainly grazed on lowland pastures, whereas the Intermediate group was composed of farms whose herds grazed on mountain pastures at an intermediate altitude, while the Full grazing group was mainly composed of farms with herds grazing on upland pastures at the highest altitude, with consequent changes in their botanical composition. The higher proportions of dicotyledonous species in the upland pastures may have induced partial inhibition of ruminal microflora, thus favoring an increase in C18:2n-6 and C18:3n-3 concentrations as well as in all their biohydrogenation intermediate products (Leiber et al., 2005). However, the results obtained in this study are in line with the results on the effect of fresh herbage proportions in cow diets demonstrated by Couvreur et al. (2006) in controlled conditions or in on-farm conditions in other territorial contexts (i.e. Ferlay et al., 2008; Coppa et al., 2012, 2013).

\subsection{Effect of herbage phenology in on-farm conditions}

When validating on-farm the results obtained in controlled conditions concerning the effect of fresh herbage phenology on milk FA concentrations, the differences between the early phenology- and the late phenology-derived milk within each farming system can be confirmed, even though for a lower number of FA. The fresh herbage proportion in cow diet has had an important effect on almost all the FA concentrations in the milk, a result that is in agreement with previous findings (Coppa et al., 2013; Couvreur et al., 2006). However, an increase in milk C18:0, C18:1c9 and total C18:1cis isomers, and a decrease in the C18:1t11, CLAc9t11, total C18:1trans isomers and PUFA concentrations has been observed in the diet in which fresh herbage was the main ingredient, when it was fed at a late rather than early phenological stage. The extent of these differences was important, as the full grazing milk produced from mature herbage had similar C18:1t11 and CLAc9t11 concentrations to those achieved with only $75 \%$ of the diet DM of fresh herbage grazed at an early phenological stage (Fig. 2). This result could have important practical applications in the case of the introduction of milk price premiums based on its FA composition. Full grazing could be advantageous as increasing the fresh herbage proportion in cow diets increases the milk concentration of several health promoting FA and decreases several unfavorable health FA (Coppa et al., 2013; Couvreur et al., 2006). However, full grazing implies not using any dietary supplements, and this feeding strategy could be unfavorable in covering the energy requirements of the animals for lactation, with a consequent drop in milk yield (Pomiés et al., 2013). On the basis of our results it can be stated that a correct management of the herbage phenology could allow the same FA profile of full grazing herds to be achieved for a lower proportion of herbage in the cow diet, thus leaving space for additional supplements to better satisfy animal requirements, to achieve higher milk yields, and to reduce the drop in milk yield during the grazing season (Farruggia et al., 2014).

On the contrary, when cows are fed low fresh herbage proportions, the effect of the herbage phenological stage found in controlled conditions was not verified at an on-farm scale (Fig. 2). This result is in agreement with those presented by Borreani et al. (2013) for intensive dairy farming systems that used small amounts of fresh herbage in cow diets. The FA profile of the milk derived from these systems seems to be affected much more by concentrates (usually given in high amounts) than by fresh herbage. In fact, in the studied intensive dairy farming systems that feed cows with fresh herbage, farmers are used to supplementing cows with high amounts of concentrate to counteract the milk yield drop due to rapid variations in herbage quality with the evolution of the phenology. As a consequence, fresh herbage becomes a secondary dietary lipid source (mainly replaced by concentrates and corn silage) and the differences related to its phenology in milk become negligible.

\section{Conclusions}

This work has highlighted the important effect of the phenology of fresh herbage on milk FA concentration in dairy systems with different fresh herbage proportions in cow diet. The results obtained in controlled conditions have been confirmed in on-farm conditions. The C18:1t11 and CLAc9t11 were the most sensitive FA to the effect of fresh herbage phenology on farms. When a low fresh herbage proportion has been used in a cow diet, the effect of herbage phenology on the milk FA concentration has been significant in controlled conditions, but negligible in the on-farm conditions. 


\section{Conflict of interest}

The authors declared that no conflict of interest.

\section{Acknowledgments}

Part of this work was funded by the Fondazione Cassa di Risparmio di Cuneo (CRC), Project "MIGLIORLAT - Miglioramento della qualità e dello sviluppo competitive della filiera latte piemontese”, Bando Ricerca Scientifica 2011.

\section{References}

Aufrère, J., Michalet-Doreau, B., 1983. In vivo digestibility and prediction of digestibility of some by-products. In: Boucqué, C.V., Fiems, L.O., Cottyn, G.B. (Eds.), EEC Seminar EUR 8918 EN Feeding Value of By-Products and Their Use by Beef Cattle. Commission of the European Union, Brussels, Luxembourg, pp. 25-35.

Association of Official Analytical Chemists International, 2005. Official Methods of Analysis, 18th ed. AOAC Int., Gaithersburg, MD, USA.

Bugaud, C., Buchin, S., Hauwuy, A., Coluon, J.B., 2002. Texture et flaveur du fromage selon la nature du pâturage: cas du fromage d'Abondance. INRA Prod. Anim. 15, 31-36.

Borreani, G., Coppa, M., Revello-Chion, A., Comino, L., Giaccone, D., Ferlay, A., Tabacco, E., 2013. Effect of different feeding strategies in intensive dairy farming systems on milk fatty acid profiles, and implications on feeding costs in Italy. J. Dairy. Sci. 96, 6840-6855.

Braun-Blanquet, J., 1932. In: Fuller, G.D., Conard, H.S. (Eds.), Plant Sociology. McGraw-Hill Book Company, Inc., New York, US,

Buccioni, A., Decandia, M., Minieri, S., Molle, G., Cabiddu, A., 2012. Lipid metabolism in the rumen: new insights on lipolysis and biohydrogenation with an emphasis on the role of endogenous plant factors. Anim. Feed Sci. Technol. 174, 1-25.

Cabiddu, A., Decandia, M., Addis, M., Piredda, G., Pirisi, A., Molle, G., 2005. Managing Mediterranean pastures in order to enhance the level of beneficial fatty acids in sheep milk. Small Rumin. Res. 59, 168-180.

Cabiddu, A., Salis, M., Tweed, J.J.S., Molle, G., Decandia, M., Lee, M.R.F., 2010. The influence of plant polyphenols on lipolysis and biohydrogenation in dried forages at different phenological stages: in vitro study. J. Sci. Food Agric. 90, 829-835.

Chilliard, Y., Glasser, F., Ferlay, A., Bernard, L., Rouel, J., Doreau, M., 2007. Diet, rumen biohydrogenation and nutritional quality of cow and goat milk fat. Eur. J. Lipid Sci. Technol. 109, 828-855.

Coppa, M., Farruggia, A., Ravaglia, P., Pomiès, D., Borreani, G., Le Morvan, A., Ferlay, A., 2015. Frequent moving of grazing dairy cows to new paddocks increases the variability of milk fatty acid composition. Animal 9, 604-613.

Coppa, M., Ferlay, A., Chassaing, C., Agabriel, C., Glasser, F., Chilliard, Y., Borreani, G., Barcarolo, R., Baars, T., Kusche, D., Harstad, O.M., Verbič, J., Golecký, J., Martin, B., 2013. Prediction of bulk milk fatty acid composition based on farming practices collected through on-farm surveys. J. Dairy Sci. 96, $4197-4211$.

Coppa, M., Gorlier, A., Lonati, M., Martin, B., Russo, E.M., Lombardi, G., 2012. The management of the transition from hay to pasture-based diets affects milk fatty acid kinetics. Dairy Sci. Technol. 92, 279-295.

Coppa, M., Verdier-Metz, I., Ferlay, A., Pradel, P., Didienne, R., Farruggia, A., Montel, M.C., Martin, B., 2011. Effect of different grazing systems on upland pastures compared with hay diet on cheese sensory properties evaluated at different ripening times. Int. Dairy J. 21, 815-822.

Collomb, M., Bütikofer, U., Sieber, R., Jeangros, B., Bosset, J.O., 2002. Correlations between fatty acids in cows' milk fat produced in the lowland, mountain and highlands of Switzerland and botanical composition of the fodder. Int. Dairy J. 12, 661-666.

Couvreur, S., Hurtaud, C., Lopez, C., Delaby, L., Peyraud, J.L., 2006. The linear relationship between the proportion of fresh grass in the cow diet, milk fatty acid composition, and butter properties. J. Dairy Sci. 89, 1956-1969.

Dewhurst, R.J., Shingfield, K.J., Lee, M.R.F., Scollan, N.D., 2006. Increasing the concentrations of beneficial polyunsaturated fatty acids in milk produced by dairy cows in high-forage systems. Anim. Feed Sci. Technol. 131, 168-206.

Dulphy, J.-P., Demarquilly, C., Baumont, R., Jailler, M., L'Hotelier, L., Dragomir, C., 1999. Study of modes of preparation of fresh and conserved forage samples for measurement of their dry matter and nitrogen degradations in the rumen. Ann. Zootech. 48, 275-288.

Elgersma, A., Tamminga, S., Ellen, G., 2006. Modifying milk composition through forage. Anim. Feed Sci. Technol. 131, 207-225.

Farruggia, A., Pomiès, D., Coppa, M., Ferlay, A., Verdier-Metz, I., Le Morvan, A., Bethier, A., Pompanon, F., Troquier, O., Martin, B., 2014. Animal performances, pasture biodiversity and dairy product quality: how it works in contrasted mountain grazing systems. Agric. Ecosyst. Environ. 185, $231-244$.

Ferlay, A., Martin, B., Pradel, P., Coulon, J.B., Chilliard, Y., 2006. Influence of grass-based diets on milk fatty acid composition and milk lipolytic system in Tarentaise and Montbéliarde cow breeds. J. Dairy Sci. 8, 4026-4041.

Ferlay, A., Agabriel, C., Sibra, C., Journal, C., Martin, B., Chilliard, Y., 2008. Tanker milk variability of fatty acids according to farm feeding and husbandry practices in a French semi-mountain area. Dairy Sci. Technol. 88, 193-215.

Ferlay, A., Martin, B., Lerch, S., Gobert, M., Pradel, P., Chilliard, Y., 2010. Effects of supplementation of maize silage diets with extruded linseed, vitamin E and plant extracts rich in polyphenols, and morning v. evening milking on milk fatty acid profiles in Holstein and Montbéliarde cows. Animal 4 , 627-640.

Givens, D.I., 2010. Milk and meat in our diet: good or bad for health? Animal 4, 1941-1952.

Glasser, F., Doreau, M., Maxin, G., Baumont, R., 2013. Fat and fatty acid content and composition of forages: a meta-analysis. Anim. Feed Sci. Technol. 185 $19-34$.

Hurtaud, C., Peyraud, J.L., Michel, G., Berthelot, D., Delaby, L., 2009. Winter feeding systems and dairy cow breed have an impact on milk composition and flavour of two protected designation of origin French cheeses. Animal 3, 1327-1338.

Kälber, T., Krauzer, M., Leiber, F., 2014. Milk fatty acid composition of dairy cows fed green whole-plant buckwheat, phacelia or chicory in their vegetative or reproductive stage. Anim. Feed Sci. Technol. 193, 71-83.

Khan, N.A., Cone, J.W., Fievez, V., Hendriks, W.H., 2012. Causes of variation in fatty acid content and composition in grass and maize silages. Anim. Feed Sci. Technol. 174, 36-45.

Kratz, M., Baars, T., Guyenet, S., 2013. The relationship between high-fat dairy consumption and obesity, cardiovascular, and metabolic disease. Eur. J. Nutr. 52, 1-24

Leiber, F., Kreuzer, M., Nigg, D., Wettstein, H.R., Scheeder, M.R.L., 2005. A study on the causes for the elevated $n-3$ fatty acids in cows' milk of Alpine origin. Lipids 40, 191-202.

Peeters, A., 2012. Past and future of European grasslands. The challenge of the CAP towards 2020. In: Goliński, P., Warda, M., Stypiński, P. (Eds.), Grassland: An European Resource? Grassland Science in Europe 17: Proceedings of the 24th General Meeting of the European Grassland Federation. Polish Grassland Society, Warsaw, pp. 17-32.

Pomiés, D., Martin, B., Pradel, P., Verdier-Metz, I., Constant, I., Delbès-Paus, C., Troquier, O., Fournier, F., Montel, M.C., Farruggia, A., 2013. Design of low-input dairy farming systems in mountain areas: animal performances and cheese sensory properties. In: Lombardi, G., Mosimann, E., Gorlier, A., Iussig, G., Lonati, M., Pittarello, M., Probo, M. (Eds.), Pastoralism and Ecosystem Conservation: Proc. of the 17th Meeting of the FAO-CIHEAM Mountain Pasture Network, Turin. , pp. 22-26. 
Revello-Chion, A., Tabacco, E., Giaccone, D., Peiretti, P.G., Battelli, G., Borreani, G., 2010. Variation of fatty acid and terpene profile in mountain milk and "Toma Piemontese" cheese as affected by diet composition in different seasons. Food Chem. 121, 393-399.

Revello-Chion, A., Tabacco, E., Peiretti, P.G., Borreani, G., 2011. Variation in the fatty acid composition of alpine grassland during spring and summer. Agron. J. 103, 1072-1080.

Robertson, J.B., Van Soest, P.J., 1981. The detergent system of analysis and its application to human foods. In: James, W.P.T., Theander, O. (Eds.), The Analysis of Dietary Fiber in Food. Marcel Dekker, New York.

Shingfield, K.J., Bonnet, M., Scollan, N.D., 2013. Recent developments in altering the fatty acid composition of ruminant-derived foods. Animal 7, $132-162$.

Van Soest, P.J., Robertson, J.B., Lewis, B.A., 1991. Methods of dietary fiber, neutral detergent fiber and non-polysaccharides in relation to animal nutrition. J. Dairy Sci. 74, 3583-3597.

Vanhatalo, A., Kuoppala, K., Toivonen, V., Shingfield, K.J., 2007. Effects of forage species and stage of maturity on bovine milk fatty acid composition. Eur. J. Lipid Sci. Technol. 109, 856-867.

Vlaemink, B., Fievez, V., Cabrita, A.R.J., Fonseca, A.J.M., Dewhurst, R.J., 2006. Factors affecting odd- and branched-chain fatty acids in milk: a review. Anim. Feed Sci. Technol. 131, 389-417. 